\title{
The Types of Aloe Species and Their Multi-Functions in Hammer District of Southern Ethiopia
}

\author{
Asmelash Tesfaye Gebremedhin* \\ Southern Agricultural Research Institute (SARI) Jinka Agricultural Research Centre (JARC), Ethiopia
}

Submission: December 22, 2017; Published: February 05, 2018

*Corresponding author: Asmelash Tesfaye Gebremedhin, Southern Agricultural Research Institute (SARI) Jinka Agricultural Research Centre (JARC), Jinka, Ethiopia, Email address: tesfayeasmelash@yahoo.com

\begin{abstract}
Aloes are a multi-functional perennial with or without woody trunks. It is extensively distributed in sub-Saharan Africa, Madagascar and other South Africa nearly islands. Forty six aloes species were recognized in Ethiopia out of which 24 species are endemic. Multi-stage sampling was employed to select representative Kebeles for both bio-physical and socio-economic surveys. Transect lines and square quadrants were laid out between $1 \mathrm{Km}$ and 600 meters respectively. Six aloe species were found in Hammer district of the southern Ethiopia. Their multi-functionality was assessed through conducting focus group discussions with different members of the pastoral and agro-pastoral communities at six discrete kebeles of the district.

The pastoral and agro-pastoral communities were inhabited in this arid and semi-arid areas were often considered as communities with fewer livelihood options. Thus, sustainable utilizations of multi-purpose perennials such as: aloes is playing very crucial role for widening the livelihood options. Fewer studies regarding distribution, ecology and benefits have been conducted so far in Ethiopia and it is highly recognizable. However, as the potential of the resource and expected outputs for nearby communities still further research and adoption of proven technologies are needed to conduct so as to devise successful utilization strategies.
\end{abstract}

Keywords : Acacia-Commiphora; Combretum-Terminalia; Arid and Semi-Arid areas; Pastoral and Agro-pastoral communities

\section{Introduction}

Aloes are belonging to the family (Aloeceae) and they are perennials with or without woody trunk and Aloes is the genus from the seven genera included in the family [1]. Aloe species occupied wider ranges of habitat and assumed to have various growth forms [2,3]. The genus, which includes about 400 species, it has mainly distributed in southern Africa, including Madagascar and the Mascarenes (Cousins and Witkowski, 2012). Forty six species of Aloes were recognized in Ethiopia and Eritrea out of which 24 Aloe species are endemic to Ethiopia [1].

This unique group of succulent plants provokes wideranging interest among both scientists and plant collectors $[2,4]$. It was believed that an immense indigenous knowledge has been expected to found in local communities whom inhabited nearby Aloes potentially grown areas. Using Aloes leaves exudates for medicinal purpose was dated back thousands of years in the history [5]. Trade in wild and cultivated Aloes for health products is central to the livelihoods of many people in Arid and Semi-Arid lands where the cultivation of conventional crops is unfeasible (Cousins \& Witkowski, 2012).

In spite of the potential benefits which tapped from this plant species very few studies has been conducted so far in Ethiopia [6] and indeed there was a considerable baseline information's regarding their distributions, ecology and importance's but still further studies need to look forward so as to devising sustainable utilization strategies to be placed at local and regional levels. The objectives of this short communication are; to confirm the existence of six Aloe species found in Hammer District of Southern Ethiopia and to switch further studies fordocumenting the local community experiences on utilization of existing Aloes species.

\section{Materials and Methods}

\section{Vegetation Survey}

Multi-stage sampling method was employed for the present study, six potential kebeles were chosen from the district. Communal woodlands were purposively selected from each kebeles based on the potential abundance of aloe species. Transect lines were laid out with $1 \mathrm{~km}$ interval between consecutive lines and $40 \mathrm{X} 40$ meter square quadrants were established with 600 meters interval along the transect lines. Full enumeration of woody plants including aloes were employed and recorded with pre-design word sheets.

During the excursion six aloe species were recognized (Aloe rivae baker, Aloe otallensis Baker, Aloe calidophila Reynolds, Aloe yavellana Reynolds, Aloe rugosifolia Gilbert and Sebsebe and 
Aloe pirottae Berger). According to the local community naming these six aloes were divide into two groups and locally names "Wollqentti" and "Gellab Wollqentti" for the first four and the latter two species respectively.

Moreover, these grouped Aloes species could have different distributions and accordingly, the first four species were highly frequent in upper Humid Qollaperiphery of the district while the latter two species were highly frequent in lower Dry Qolla periphery of the district. Regarding the associated vegetation categories the upper periphery more dominated with CombretumTerminalia woodland and wooded grassland type of vegetation while the lower periphery is tended to Acacia-Commiphora wood land and bush land vegetation type. Different naming by the local community might be related with observations of existing distribution differences among the Aloes species and of course they used a name of neighbours as suffice especially for plants inhabited adjoining to the neighbours. This experiences of naming were depicted in the second group of Aloes the word "Gellab" were belong to the name of Dassenech ethnic group whom shared a boundary in the lower south - western periphery of the district. Further reading about their ecology, distribution and uses was described elsewhere [1].

Three focus group discussions (FGD's) were held in three Kebeles (lower administration unit of the country) of the Hammer district. Each group has a member of 9-11 individuals of the community with different social classes, gender and ages. However, it was believed that elders are the foremost to know folk medicine and hence, the team tried to encompass more elders as possible while organizing the focus group teams. Indeed they were discussed regarding the possible utilities of Aloes as remedy for various diseases and disorders which recurred in Human and livestock's lives.

\section{Multi-Purpose Benefits as Pronounced by the Local Community}

According to the FGD's Aloes were good sources of feed (browsed directly and chopped) and moisture for goats especially during dry season. This is in line with aloes as a source of browse for livestock's and elephants somewhere in Africa [7]. The aloe latex was potentially used for remedy of snack bite. They used to mix Aloe latex with certain proportions (1:40 ratio) of water and enforced to drink the one who have bitten as short as possible after the attack. They used Aloe sap: for worms and internal parasites both for human and livestock's as well, they rubbed on injured and scarred skin so as to fasten the healing process, to abort a child during early phases of pregnancy, to overcome malaria disease and its symptoms and finally it is used to cease a child from breast feeding. The medicinal role of Aloe specie is believed to be due to the synergistic action of different compounds and constituents [8] and this in turns it maximize the multi-functionality of the Aloes for wider spectrum of disease and disorders.
Moreover, the Aloes flowers are appreciable sources of bee forage and this is in line with the reports of [9] they argue that Aloes are a good source of moisture and carbohydrates for honeybees especially when other feed sources are in adequate. This is mainly due to the fact that producing considerable amount of nectar for honey production [1]. And this in turn it secures high production of honey especially for pastoralist communities whom honey production is the third main source of income followed to livestock rearing and opportunistic crop productions.

Majority of aloes thrive in almost any soil type, requiring neither any fertilizer nor any special soil preparation before planting [2] they are found flourishing on nutrient deficient, rocky or gravelly soils [10] and well adapted for moisture stress and highly disturbed areas [6]. This might be the fact that adventitious root systems that grow only a few centimetres below the soil surface allow aloes to benefit from relatively low amounts of precipitation [11]. The aloe fleshy leaves, stems, or occasionally fleshy fusi form roots can store a large amount of water this makes to survive even with exceeding high temperature and consequent high evapo transpiration through refilling the water losses within a day after relief from heat and drought stress [12]. On the other hand there were findings which showed that juveniles are depending on certain amount of moisture inputs for survival in arid ecosystems [13]. This seems to be the response of aloes for extreme environments is depend on type of species and phase of growth.

The aforementioned capabilities of the Aloe species enable them to be a key plant species for lowland ecosystems [8]. On the basis of these facts aloes would be a considerable option for rehabilitation of degraded lands: barriers for soil erosion through stabilizing soils [2] and in favour of associated plant communities facilitate litter cover, soil seed banks and soil water retention [14] as a result aloes could modify soil micro-climates (both moisture and temperature). Moreover, Aloes can serve as a nurse plant for new emerging plants [15] this is mainly due to the fact that colonising and ameliorating harsh conditions in sparsely vegetated or completely denuded landscapes $[14,16]$ and this in terns pronounced as aloe plants have a significant contribution or use for restoration of degraded ecosystems.

\section{Efforts so far Done}

There were little attentions to invest on Aloe plant species establishment, production, handling and processing in the country in general and in the region in particular. Different products and services were potentially collected from different parts of the Aloe plants. However since the last three years there was an attempt in collaboration between AFD (Action for development - domestic NGO) and the local communities. Selected members of the pastoral and agro-pastoral communities were organized, trained and eventually engaged in processing soaps from latex of aloes and other constituents. Such efforts need to be supported with organized research findings, proven technologies and in turn development strategies. 


\section{Summary}

The pastoralist communities were lived in Arid and semi-Arid areas which often considers as a land with a few livelihood options [17]. Uneven and unpredictable nature of the rainfall distribution has always been a severe constraint for both crop and pasture productions $[17,18]$. And thus, this would be the right time to look for devising strategies on sustainable utilization of existing woody and non-woody based natural resource potentials such as: aloes. With this regard perennial multi-purpose plant species such as: Aloes could play a substantial role in widening diverse sources of livelihood income for the pastoralist communities while restoring and modifying the ecosystem in certain way so as to support crop and pasture productions.

In spite of their multi-purpose potentials they were threatened due to agricultural expansions even it took place in marginal lands, habitat destruction for purposes of settlement and climate change related impacts such as; drought $[6,19,20]$. Hence, further studies are needed to be conducted on: population structure, growth pattern and multi-purpose uses across different communities with different social setups.

\section{References}

1. Sebsebe Demissew, Inger Nordal (2010) Aloes and lilies of Ethiopia and Eritrea.

2. Smith GF, Van Wyk B (2009) Aloes in Southern Africa. Struik Nature, Cape Town, South Africa.

3. Van Wyk BE, Smith G (2008) Guide to the Aloes of South Africa. Briza Publications, Pretoria, South Africa.

4. Smith GF, Steyn EMA, Victor JE, Crouch NR, Golding J (2000) The conservation status of Aloe in South Africa: an updated synopsis. Bothalia 30(2): 206-211.

5. Grace OM, Simmonds MSJ, Smith GF, Van Wyk (2009) Documented utility and biocultural value of Aloe L. (Asphodelaceae) a review. Economic Botany 63(2): 167-178.

6. Fikre Dessalegn (2013) Study on the Populations of an Endemic Aloe Species (A.Gilbertii Reynolds) in Ethiopia. IRACST-Engineering Science and Technology: An International Journal (ESTIJ) 3(3): 2250-3498.

7. Parker DM, Bernard RTF (2009) Levels of aloe mortality with and without elephants in the thicket biome of South Africa. African Journal of Ecology 47(2): 246-251.
8. Bula Kere Oda, Baressa Anbessa Erena (2017) Aloes of Ethiopia: A Review on Uses and Importance of Aloes in Ethiopia International Journal of Plant Biology \& Research 5(1): 1059.

9. Human H, Nicolson SW (2008) Flower structure and nectar availability in Aloe greatheadii var. davyana: an evaluation of a winter nectar source for honeybees. International Journal of Plant Sciences 169(2): 263-269.

10. Wabuyele E, Kyalo S (2008) Sustainable Use of East African Aloes: the Case of Commercial Aloes in Kenya. NDF Workshop Case Studies, WG3 e Succulents and Cycads, Case Study 1: Aloe spp. East and southern Africa, Mexico. P.1-17.

11. Jack SL (2012) Revisiting Aloe dichotoma's suitability as an indicator of climate change in southern Africa. MSc Thesis, University of Cape Town, Cape Town. Journal of Geoscience and Environment protection $4(7)$.

12. Newton L (2008) Will the True Aloe vera Please Stand Up! SWARA.

13. Noy Meir I (1973) Desert ecosystems: environment and producers. Annual Review of Ecology and Systematics 4: 25-51.

14. King EG (2008) Facilitative effects of Aloe secundiflora shrubs in degraded semiarid rangelands in Kenya. Journal of Arid Environments 72: 358-369.

15. King EG, Stanton ML (2008) Facilitative effects of Aloe shrubs on grass establishment, growth and reproduction in degraded Kenyan rangelands: implications for restoration. Restoration Ecology 16(3): 464-474.

16. Smith GF, Correia RI (1992) Establishment of Aloe greatheadii var. davyana from seed for use in reclamation trials. Landscape and Urban Planning 23: 47-54.

17. Worku A, Lemenih M, Fetene M, Teketay D (2011) Socio-economic importance of gum and resin resources in the dry woodlands of Borana, southern Ethiopia. Forests, Trees and Livelihoods 20(2-3): 137-155.

18. Lemenih M, Kassa H (2011) Opportunities and challenges for sustainable production and marketing of gums and resins in Ethiopia. Centre for International Forestry Research PP.105.

19. Foden W, Midgley GF, Hughes G, Bond WJ, Thuiller W, et al. (2007) A changing climate is eroding the geographical range of the Namib Desert tree Aloe through population declines and dispersal lags. Diversity and Distributions 13(5): 645-653.

20. Duncan J, Hoffman T, Rohde R, Powell E, Hendrick H (2006) Longterm population changes in the Giant Quiver tree, Aloe pillansii in the Richtersveld, South Africa. Plant Ecology 185: 73-84.

\begin{tabular}{|l|}
\hline \multicolumn{1}{|c|}{ Your next submission with Juniper Publishers } \\
will reach you the below assets \\
- Quality Editorial service \\
- Swift Peer Review \\
- Reprints availability \\
- E-prints Service \\
- Manuscript Podcast for convenient understanding \\
- Global attainment for your research \\
- Manuscript accessibility in different formats \\
( Pdf, E-pub, Full Text, Audio) \\
- Unceasing customer service \\
Track the below URL for one-step submission \\
https://juniperpublishers.com/online-submission.php \\
\hline
\end{tabular}

